\title{
A inversão do ônus da prova na decretação da perda alargada: entre o Código Penal e a Lei n. 11.343/06
}

\author{
The reversion of the burden of proof underlying the extended \\ confiscation: between the Penal Code and the Drugs Act
}

\section{Luiz Eduardo Dias Cardoso ${ }^{1}$}

Universidade Federal de Santa Catarina - Florianópolis/SC, Brasil

luizeduardo.cardoso@gmail.com

lattes.cnpq.br/7842116424496804

orcid.org/0000-0002-9432-1379

Resumo: Este artigo aborda a perda alargada, recentemente incorporada ao Código Penal (artigo 91-A) e à Lei n. 11.343/06 (artigo 63-F), e aprecia um aspecto processual em particular, atinente ao ônus da prova subjacente àquela espécie de confisco. O problema remete à seguinte indagação: a perda alargada é operacionalizada a partir da inversão do ônus da prova? A hipótese dá conta de que a resposta não é unívoca: há inversão do ônus da prova no Código Penal, mas não há na Lei de Drogas. O trabalho, cuja realização é justificada em razão da novidade e da relevância do tema, é orientado pelo método dedutivo, uma vez que parte de acepções abrangentes acerca da perda alargada e busca formular uma conclusão pontual sobre a inversão do ônus da prova. A estrutura é segmentada em três seções: apresenta-se a perda alargada, com ênfase em seus antecedentes legislativos, em suas principais nuances dogmáticas e na disciplina dada pela legislação brasileira; aprecia-se a forma como é operacionalizada a questão probatória subjacente à perda alargada nos dois diplomas que a preveem; e reflete-se quanto às repercussões da eventual inversão do ônus da prova. O resultado da pesquisa confirma a hipótese introdutoriamente articulada.

1 Doutorando, Mestre e Bacharel em Direito pela Universidade Federal de Santa Catarina (UFSC). Especialista em Direito Penal e Processo Penal (Univali e ABDConst). Professor de Direito Penal da Escola Superior da Magistratura Federal de Santa Catarina (ESMAFESC). Advogado. 
Palavras-Chave: perda alargada; confisco alargado; Código Penal; Lei de Drogas; inversão do ônus da prova.

ABSTRACT: The present article aims to analyze the extended confiscation, recently incorporated to the Penal Code (article 91-A) and to the Drugs Act (article 63-F), and focuses on a specific procedural issue, regarding the burden of proof underlying the extended confiscation. The research problem can be summarized as the following: does the extended confiscation work based on a reversion of the burden of proof? The hypothesis points that there are two answers: reversion of proof exists in the Penal Code, however, it cannot be found in the Drugs Act. This paper, which is justified by the theme's relevance and novelty, is guided by the deductive method, because it begins with broad considerations regarding the extended confiscation and aims to find a specific conclusion about the reversion of the burden of proof. Firstly, it presents the extended confiscation, emphasizing its legislative background, its main characteristics and Brazil's laws. Later, the article shows how the proof regarding the extended confiscation is produced according both to the Penal Code and to the Drugs Act; finally, it reflects on the consequences following the reversion of the burden of proof. The research's result confirms the hypothesis initially drawn.

Keywords: extended confiscation; Penal Code; Drugs Act; reversion of the burden of proof.

SuMÁRIO: Introdução; 1. Breve panorama quanto à perda alargada: principais nuances dogmáticas e legislativas; 1.1. Panorama legislativo e político-criminal da perda alargada; 1.2. A perda alargada na legislação penal brasileira: um instituto, dois regimes; 2 . Entre a redução do standard probatório e a inversão do ônus da prova; 3. Repercussões da inversão do ônus da prova na disciplina da perda alargada; Considerações Finais; Referências.

\section{INTRODUÇÃO}

A perda alargada é instrumento que permite o confisco não apenas dos bens diretamente vinculados ao crime pelo qual o agente é condenado, mas também de toda a parcela de seu patrimônio que seja incompatível com seus rendimentos lícitos. 
Trata-se de modalidade de confisco adotada em diversos países europeus a partir do final do século XX (GODINHO, 2004, p. 1.321), cujo objetivo principal consiste no enfrentamento à criminalidade econômica organizada.

Sobretudo a partir dos anos 2000, intensificou-se a tendência de adoção de instrumentos confiscatórios cujo âmbito de incidência vai além daquelas modalidades de perda que já se encontravam previstas nos Códigos Penais, das quais é exemplo a perda clássica, disciplinada no artigo 91, II, $b$, do Código Penal brasileiro.

O Brasil não se manteve alheio a essa tendência. Embora já houvesse tímidas discussões doutrinárias pretéritas, a perda alargada passou a ser mais intensamente discutida em território nacional a partir de 2015, com a proposição das Dez Medidas Contra a Corrupção e de diversos outros projetos legislativos que se seguiram.

De todo modo, apenas com a proposição de outro conjunto de medidas, o Pacote Anticrime, a perda alargada foi efetivamente incorporada à legislação penal brasileira, com o acréscimo, pela Lei n. 13.964/2019, do artigo 91-A ao Código Penal, ultimado em janeiro de 2020. Pouco antes disso, todavia, a perda alargada foi acrescida à Lei de Drogas, em seu artigo 63-F, com a promulgação da Lei n. 13.886/2019.

Com a incorporação da perda alargada à legislação penal brasileira, as discussões doutrinárias a respeito desse novo instituto, antes pouco numerosas, certamente se multiplicarão. Além disso, em sentido semelhante, a aplicação judicial da perda tem o potencial de provocar dissonâncias interpretativas por ocasião de sua análise pelos tribunais. Essas dúvidas e discussões devem ser potencializadas pelo fato de se tratar de instituto absolutamente novo, munido de métodos e técnicas pouco ortodoxos, até pouco tempo estranhos à legislação nacional. Não fosse isso suficiente, a consagração de uma técnica legislativa lacunosa e dúbia deve incrementar as dificuldades que naturalmente já circundam a perda alargada.

Esse instituto, muito embora seja, em última análise, um instrumento de Direito Penal material - não à toa consagrado no Código Penal -, também possui relevantes aspectos processuais, que, da mesma forma, têm o potencial de gerar divergências doutrinárias e jurisprudenciais.

Aquele que possivelmente mais suscitará dissonâncias diz respeito à inversão do ônus da prova subjacente à perda alargada. Com efeito, as 
convenções internacionais que discorrem acerca da perda alargada preveem a possibilidade - e não a obrigatoriedade - de inversão dos ônus probatórios, de forma que se imponha à defesa o encargo de comprovar a licitude do patrimônio do condenado. Nessa linha, em boa parte dos ordenamentos jurídicos que a consagram, a perda alargada é efetivamente operacionalizada a partir de uma inversão do ônus da prova.

Por conta do tortuoso processo legislativo pelo qual passou a perda alargada no parlamento brasileiro, não está claro se a sua operacionalização ocorre, de fato, a partir dessa inversão dos encargos probatórios. Para adicionar ainda mais complexidade à discussão, o cenário legislativo apresenta uma dicotomia regulatória em relação à matéria, uma vez que a disciplina adotada no artigo 91-A Código Penal é distinta daquela encontrada no artigo 63-F da Lei de Drogas.

Nesse cenário, é em torno deste aspecto processual da perda alargada que orbita o presente artigo. Seu objeto consiste, pois, na própria perda alargada e, mais estritamente, no ônus probatório subjacente àquele instituto.

O problema de pesquisa que suscita o desenvolvimento da presente pesquisa pode ser sintetizado na seguinte indagação: de acordo com o artigo 91-A do Código Penal e o artigo 63-F da Lei de Drogas, a perda alargada é operacionalizada a partir de uma lógica de inversão do ônus da prova? Busca-se, em outras palavras, compreender se uma leitura guiada pelo método de interpretação textual ou literal poderia levar à conclusão de que os aludidos dispositivos legais invertem o ônus da prova em desfavor da defesa por ocasião da decretação da perda alargada.

A resposta à questão acima delineada há de ser formulada a partir do método dedutivo, uma vez que o presente artigo parte de considerações abrangentes a respeito da perda alargada - sua consagração em leis e convenções internacionais, bem como suas principais nuances dogmáticas - para desenvolver conclusão específica a partir de um aspecto particular daquele instrumento penal: o ônus probatório que lhe é subjacente.

A hipótese provisoriamente articulada dá conta de que, exatamente em razão da dicotomia que caracteriza a regulamentação legal da perda alargada, a resposta à indagação antes formulada não é unívoca: assim, conjectura-se que a perda alargada prevista no Código Penal é 
operacionalizada a partir da inversão do ônus da prova, ao passo que aquela contida na Lei de Drogas não o é.

Para verificar ou falsear a hipótese acima apresentada, este artigo é estruturado em três seções.

Na primeira delas, apresenta-se uma introdução à perda alargada, com a indicação de suas origens normativas - principalmente das convenções internacionais que a preveem, das quais o Brasil é signatário -, de suas principais nuances dogmáticas e da disciplina que foi consagrada no Código Penal e na Lei de Drogas.

Na sequência, inicia-se a discussão a respeito dos aspectos probatórios subjacentes à perda alargada. Para tanto, aprecia-se a dinâmica probatória prevista nos dispositivos legais que disciplinam esse novo instrumento confiscatório. Busca-se, ainda, identificar se o artigo 91-A do Código Penal e o artigo 63-F da Lei de Drogas de fato invertem o ônus da prova em desfavor da defesa, em uma análise que deve levar em conta as peculiaridades das respectivas regulamentações. Reflete-se, ademais, quanto ao standard probatório adotado no juízo quanto à decretação da perda alargada.

Por fim, elaboram-se reflexões a respeito das repercussões práticas das conclusões formuladas, bem como apresentam-se possíveis críticas à forma como a questão probatória subjacente à perda alargada foi delineada pelo legislador brasileiro nos dois diplomas normativos que a preveem.

A realização da presente pesquisa é justificada pela considerável relevância que a questão aqui abordada assume com a consagração legal da perda alargada. Nesse sentido, a reflexão aqui proposta, apesar de teórica, tem profundas implicações práticas: além de suscitar a discussão acadêmica, busca fornecer balizas teóricas para a aplicação prática da perda alargada pelos tribunais. Acrescenta-se, ainda, tratar-se de instrumento novo, a respeito do qual a bibliografia ainda é bastante restrita no meio jurídico nacional ${ }^{2}$.

2 Não se pode ignorar, é claro, a existência de trabalhos acadêmicos brasileiros que abordam a questão da perda alargada, como é o caso dos escritos de Linhares (2016) e Vieira (2017), além de produções críticas à perda alargada, mencionadas ao longo do presente artigo. De todo modo, o estado da arte em relação à perda alargada ainda é muito incipiente na academia jurídica brasileira. 
O procedimento de pesquisa aqui adotado é o bibliográfico, com remissão destacada à legislação pertinente - em âmbito nacional, estrangeiro e internacional - e à doutrina especializada, sobretudo de países nos quais a perda alargada já é adotada e, portanto, já apresenta discussões relativamente consolidadas a respeito de tal instituto, tanto em âmbito doutrinário quanto em âmbito jurisprudencial. Destacam-se, aqui, a doutrina, a jurisprudência e a legislação portuguesas, nas quais as discussões a respeito da perda alargada, apesar de ainda bastante vívidas, estão relativamente consolidadas; assim, embora não haja consenso em relação a todos aspectos que circundam a perda alargada, as discussões daí decorrentes alcançaram um grau de maturidade acadêmica, até porque já se passaram duas décadas desde a incorporação da perda alargada ao ordenamento jurídico português, com a Lei n. 5/2002.

O objetivo geral aqui almejado consiste em elucidar a operacionalização probatória da perda alargada, especialmente no que toca à inversão do ônus da prova em desfavor da defesa. Os objetivos específicos consubstanciam-se na introdução da perda alargada e de seus aspectos dogmáticos e normativos mais destacados; na discussão acerca dos aspectos probatórios envoltos no requerimento e na decretação da perda alargada; e na reflexão acerca das repercussões práticas e doutrinárias decorrentes da inversão do ônus da prova subjacente à perda alargada.

Por limitações de tempo e espaço, a trajetória traçada neste artigo passará ao largo de outras questões atinentes à perda alargada que, ainda que transitoriamente mencionadas, suscitam divergências cujo debate demanda pesquisas apartadas ${ }^{3}$.

3 Duas das questões cuja ausência neste escrito possivelmente será sentida dizem respeito à conformidade constitucional e à natureza jurídica da perda alargada. Em ambos os casos, o enfrentamento dos temas demandaria análises amplas e profundas, que, por não serem o cerne deste escrito, não encontram aqui seu lugar. De todo modo, vale consignar, antecipando estudos futuros, que a adequação da perda alargada à ordem constitucional, sobretudo no caso da disciplina dada pelo Código Penal, demandaria um esforço interpretativo e integrativo bastante significativo; é duvidosa, para dizer o mínimo, a constitucionalidade da perda alargada. Quanto à natureza jurídica do instituto, a própria topografia legal o qualifica como efeito secundário da condenação; no que toca ao caráter penal ou extrapenal, mantém-se, por ora, a concepção de que se trata de instrumento penal (CARDOSO; SOUZA, 2016, p. 240). 
Expostos os elementos metodológicos que conformam este trabalho, passa-se a discorrer acerca das principais nuances dogmáticas e legislativas da perda alargada.

\section{BreVe panorama quanto À Perda alargada: PRINCIPAIS NUANCES DOGMÁTICAS E LEGISLATIVAS}

A perda alargada ${ }^{4}$ consubstancia, como se antecipou acima, instrumento ${ }^{5}$ que permite que se decrete o confisco ${ }^{6}$ não apenas dos bens vinculados a uma infração pela qual o agente é condenado (artigo 91,

4 Este trabalho, quando alude à perda alargada, naturalmente refere-se ao modelo agora consagrado pela legislação penal brasileira, o qual, apesar de algumas divergências, encontra paralelo muito semelhante na perda alargada à portuguesa, prevista na Lei n. 5/2002. Esse esclarecimento é útil porque não existe um só modelo de perda alargada, como se extrai, por exemplo, da Decisão-quadro 2005/212/JAI, importante instrumento normativo editado no âmbito da União Europeia, que exorta os Estados-Membros à adoção de algum dos três diferentes modelos de perda alargada ali previstos (mais tarde unificados pela Diretiva 2014/42/UE). Alerte-se que, por vezes, outros autores veiculam a expressão "confisco alargado" para aludir a institutos distintos daquele abordado no presente artigo, como é o caso em Rios e Pujol (2016) em que os autores se debruçam, em verdade, sobre a ação civil de extinção de domínio - e em Lucchesi (2017), em que o autor aprecia a perda de bens no ordenamento jurídico norte-americano, a qual, mais uma vez, mais se assemelha à perda civil de bens. Em sentido semelhante, vale observar que o Supremo Tribunal Federal, no voto condutor do acordão proferido no julgamento do Recurso Extraordinário n. 638.491/PR (Rel. Min. Luiz Fux, julgamento em 17/05/2017), também utilizou a expressão "confisco alargado", equiparando tal instrumento, equivocadamente, àquela espécie de confisco prevista no artigo 243 da Constituição Federal.

5 Em âmbito material, a discussão quanto à natureza jurídica da perda alargada é uma das que suscita as maiores divergências, especialmente na doutrina portuguesa. Para uma síntese quanto ao tema, remete-se a Essado (2014, p. 18).

6 Apesar de algum dissenso doutrinário, este trabalho utiliza, indistintamente, as expressões "confisco" e "perda”. Embora, como narra Dias (2018, p. 133-134) alguns autores defendam a inadequação do termo "perda”, é essa a expressão que foi adotada pela legislação portuguesa, pela Diretiva 2014/42/ UE e pela própria legislação brasileira. Além disso, a discussão parece ser desprovida de repercussão prática. Por oportuno, salienta-se que também não há distinção entre as expressões "perda alargada" e "confisco alargado", também indistintamente utilizadas neste escrito. 
II, $b$, do Código Penal) ou de valores equivalentes (artigo 91, § $1^{\circ}$ ), mas também de toda a parcela de seu patrimônio que se afigure incompatível com seus rendimentos lícitos.

Com o objetivo de apresentá-la - pelo menos em relação a seus aspectos mais relevantes -, discorre-se, aqui, a respeito de seus antecedentes legislativos (na esfera internacional e no ordenamento jurídico de outras nações) e de sua regulamentação no Brasil, com a exposição de suas principais nuances dogmáticas.

\subsection{Panorama legislativo e político-criminal da perda alargada}

Como narra Godinho (2004, p. 1.321), a perda alargada existe pelo menos desde 1986, com a sua consagração na legislação britânica, à qual se seguiram, nos anos seguintes, previsões nos ordenamentos da Austrália (1987), da Alemanha e da Holanda (1992). Portugal consagrou a perda alargada em 2002, por meio da Lei n. 5/2002. Na legislação norte-americana há a previsão de modalidades "alargadas” de confisco pelo menos desde a década de 1970, mas o paralelo com os Estados Unidos da América é menos usual, em razão das peculiaridades que lhe são características ${ }^{7}$.

Para além dos ordenamentos jurídicos nacionais, é relevante a menção às convenções internacionais que, de uma forma ou de outra, dão sustento a instrumentos alargados de confisco.

A primeira delas é a Convenção de Viena (Convenção Contra o Tráfico Ilícito de Entorpecentes e Substâncias Psicotrópicas, de 1988), a qual, ao discorrer sobre o confisco, estipula o seguinte (artigo 5, item 7):

Cada Parte considerará a possibilidade de inverter o ônus da prova com respeito à origem lícita do suposto produto ou outros bens sujeitos a confisco, na medida em que isto seja compatível com os princípios de direito interno e com a natureza de seus procedimentos jurídicos e de outros procedimentos.

7 Uma compreensiva visão panorâmica sobre o "confisco alargado" americano é apresentada por Lucchesi (2017). 
Logo se vê, então, a razão para o destaque da Convenção de Viena: é a primeira em que se prevê a possibilidade - e, frise-se, não a obrigatoriedade - de inversão do ônus da prova quanto à licitude do patrimônio do condenado, contanto que previsão nesse sentido seja compatível com o direito inteiro. A Convenção, além disso, apresentou uma definição de “confisco": "Por 'confisco' se entende a privação em caráter definitivo, de algum bem, por decisão de um tribunal ou de outra autoridade competente" (artigo 1,e).

À Convenção de Viena seguiram-se a Convenção de Palermo (contra o Crime Organizado Transnacional, de 2000) e a Convenção de Mérida (contra a Corrupção, de 2003), as quais reiteraram as disposições antecedentes.

No âmbito da União Europeia, vale destacar, quanto à perda alargada, a Decisão-Quadro 2005/212/JAI ${ }^{8}$, que exortou os Estados-Membros a adotar, alternativamente, um dos três modelos de perda alargada previstos nesse instrumento normativo.

Quase uma década se passou até que, após experimentar severos problemas de harmonização legislativa e de cooperação judiciária - decorrentes da pluralidade de regimes indicados na Decisão-Quadro 2005/212/ JAI e daqueles já previamente adotados pelos Estados-Membros -, a União Europeia editou a Diretiva 2014/42. Com esse instrumento, a Comunidade Europeia buscou, primordialmente, superar os problemas de harmonização que obstavam uma cooperação judiciária eficiente. Trata-se de um relevante marco nesse recente trajeto por que passou a perda alargada.

As repercussões da Diretiva 2014/42 foram sentidas em toda Europa. Em Portugal, por exemplo, promulgou-se a Lei n. 30/2017, que "transpõe a Diretiva 2014/42/UE, do Parlamento Europeu e do Conselho, de 3 de abril de 2014, sobre o congelamento e a perda dos instrumentos e produtos do crime na União Europeia”.

Portugal é um exemplo bastante emblemático quanto aos efeitos da Diretiva em questão. De fato, após a Lei n. 5/2002, a perda alargada foi pouco acionada no enfrentamento à delinquência econômica levado a cabo pelas autoridades persecutórias portuguesas. Esse instrumento

8 Segundo Essado (2014, p. 100), “o principal objetivo de uma decisão-quadro é aproximar as disposições legislativas e regulamentares dos Estados-Membros”. 
passou, como diz a doutrina lusa, por uma "fase platônica" (SIMÕES, 2010, p. 184) - o que se deve, pelo menos em parte, à resistência da doutrina em aceitar tão peculiar instituto -, mas, com a criação do Gabinete de Recuperação de Ativos pela Lei n. 45/2011 e sobretudo com a influência da Diretiva 2014/42, sua utilização passou a constituir diretriz central da política criminal portuguesa?.

Toda essa tendência legislativa tendente ao fortalecimento das iniciativas de recuperação de ativos, que vem se avolumando nos últimos anos, tem por objetivo principal o enfrentamento à criminalidade econômica organizada, cujas peculiaridades tornam ineficazes os instrumentos clássicos dos quais se serve o Direito Penal - como a pena de prisão e até mesmo a perda "clássica".

Como não se almeja traçar, no presente trabalho, uma análise exaustiva sobre essas novas nuances que o Direito Penal - agora sob o epíteto de Direito Penal Econômico - tem assumido nas últimas décadas $^{10}$, basta anotar, aqui, duas características singulares dessa nova macrodelinquência: a continuidade com a qual suas atividades delitivas são desenvolvidas, em uma logica verdadeiramente empresarial, que "se utiliza da estrutura societária de corporação de negócios” (MALAN, 2016, p. 218), e a adoção do lucro como móbil, naquilo que se reputa constituir a "criminalidade reditícia" (CAEIRO, 2013, p. 456), que se retroalimenta a partir da obtenção de vantagens ilícitas e do subsequente reinvestimento na prática de novos delitos.

São essas peculiaridades que impulsionam a política criminal que tem sido adotada internacionalmente desde o final do século XX na direção da recuperação de ativos, em um cenário que faz surgir instrumentos de confisco com âmbitos de incidência expandidos, como é o caso da perda alargada.

9 A Lei n. 96/2017 de Portugal, que "define os objetivos, prioridades e orientações de política criminal para o biénio de 2017-2019", dispõe que "é prioritária a identificação, localização e apreensão de bens ou produtos relacionados com crimes, a desenvolver pelo Gabinete de Recuperação de Ativos” (artigo $16^{\circ}$, item 1).

10 Para esse fim, remete-se à não tão recente - mas sempre atual - obra de Sánchez (2002). 
Nesse cenário, a essência do instituto de que aqui se trata consiste na existência de uma incongruência patrimonial - entre os rendimentos lícitos do agente e o patrimônio que efetivamente detém -, que indica a existência de bens que constituem, presumivelmente, produtos ou proveitos de infrações penais anteriores àquela pela qual o agente é condenado, isto é, de uma anterior carreira criminosa. A partir dessas premissas relativamente simples, as diversas formas de regulamentação do instituto direcionam a forma como se dará o confisco de bens do condenado, que pode variar em diversos aspectos, que vão do âmbito probatório até as regras procedimentais.

\subsection{A PERda Alargada NA LEGISLAÇÃo PENAL BRASILEIRA: UM INSTITUTO, DOIS REGIMES}

O Brasil, embora com certo atraso, aderiu à mencionada tendência político-criminal. Com efeito, ainda que seja signatário daquelas três convenções da Organização das Nações Unidas, o país tardou a adotar instrumentos de confisco mais amplos do que aqueles já classicamente previstos na legislação penal.

O próprio artigo 91, II, do Código Penal, está presente desde a redação originária do estatuto punitivo, e sofreu alterações apenas redacionais por ocasião da reforma da Parte Geral havida em 1984. A essência desse dispositivo é um vínculo completo entre o bem a ser confiscado e o crime imputado ao agente. Assim, somente é possível a decretação da perda dos bens ${ }^{11}$ diretamente decorrentes de uma prática delitiva.

Mais recentemente, com a paulatina adoção das políticas criminais que ganharam força mundo afora, houve uma tímida expansão dos instrumentos de confisco, nos âmbitos processual e material. Na seara processual, vale a alusão à alienação antecipada de bens, inicialmente reservada à lavagem de dinheiro e mais tarde incorporada, em 2012, ao Código de Processo Penal (artigo 144-A).

Materialmente, é relevante a adoção, também em 2012, da perda por equivalente (ou perda subsidiária), com o acréscimo dos $\S \S 1^{\circ}$ e $2^{\circ}$

11 Ao longo deste artigo, a remissão à perda de bens refere-se, em geral, às vantagens (ou proveitos) auferidas com a prática de um delito. 
ao artigo 91 do Código Penal. Com a adoção da perda por equivalente, muito embora tenha sido mantida a limitação do confisco em relação ao valor auferido com a prática delitiva, tornou-se prescindível o nexo de causalidade entre o crime e os bens a serem confiscados - a chamada referibilidade, a que alude Essado (2014, p. 48). Tratou-se, sob essa perspectiva, de um primeiro passo no afastamento entre o crime e os bens confiscáveis.

A mudança mais significativa, todavia, ocorreu entre os anos de 2019 e 2020, com a incorporação da perda alargada à legislação penal brasileira.

O capítulo inicial dessa trajetória legislativa é, todavia, anterior: remete pelo menos a 2015, com a proposição das Dez Medidas Contra a Corrupçã $0^{12}$. No Parlamento, entretanto, o pacote foi derrotado e, assim, silenciou-se brevemente a discussão legislativa a respeito da perda alargada.

Ainda assim, diversas outras propostas legislativas ${ }^{13}$ - embora não tão notórias quanto as Dez Medidas - foram apresentadas, como é o caso das Novas Medidas Contra a Corrupção e do Projeto de Lei n. $10.372 / 2018$, redigido por comissão de juristas coordenada pelo então Ministro da Justiça (mais tarde, Ministro do Supremo Tribunal Federal) Alexandre de Moraes.

No começo de 2019, sob considerável influência das Dez Medidas, o Governo Federal apresentou o denominado Pacote Anticrime. Entre as 20 medidas então propostas, uma delas (a Medida VIII) dizia respeito, em parte, à perda alargada. Dada a relevância dessa medida, vale aludir à redação então proposta:

12 Vale observar que o pacote das Dez Medidas propôs, a par da perda alargada, a adoção da ação civil de extinção de domínio, qualificada como exemplo de non-conviction based confiscation, isto é, de instrumento confiscatório cuja decretação dispensa uma condenação criminal. O Pacote Anticrime, por outro lado, não previu a adoção dessa medida, de forma que, mesmo com previsão nesse sentido no PL 10.372/2018, a Lei n. 13.964/2019 acabou por não consagrar o instituto. A respeito do tema, v. Rios e Pujol (2016), Lucchesi (2017) e, sobretudo, Vasconcelos (2010).

13 A perda alargada é abordada nas Dez Medidas Contra a Corrupção, nas Novas Medidas Contra a Corrupção e nos seguintes Projetos de Lei: a) da Câmara dos Deputados - PLs 3.912 e 4.003, de 2015; 4.268 e 6.719, de 2016; 8.727 e 9.173, de 2017; 11.127, 11.172 e 10.372, de 2018; 13, 94 e 3.855 (anterior PL 4.850/2016, correspondente às Dez Medidas Contra a Corrupção), de 2019; b) no Senado Federal - PLS 103 e 306, ambos de 2016. 
Art. 91-A. Na hipótese de condenação por infrações às quais a lei comine pena máxima superior a seis anos de reclusão, poderá ser decretada a perda, como produto ou proveito do crime, dos bens correspondentes à diferença entre o valor do patrimônio do condenado e aquele que seja compatível com o seu rendimento lícito.

$\S 1^{\circ}$ A decretação da perda prevista no caput fica condicionada à existência de elementos probatórios que indiquem conduta criminosa habitual, reiterada ou profissional do condenado ou sua vinculação à organização criminosa.

$\S 2^{\circ}$ Para efeito da perda prevista no caput, entende-se por patrimônio do condenado todos os bens:

I - de sua titularidade, ou em relação aos quais ele tenha o domínio e o benefício direto ou indireto, na data da infração penal ou recebidos posteriormente; $\mathrm{e}$

II - transferidos a terceiros a título gratuito ou mediante contraprestação irrisória, a partir do início da atividade criminal.

$\S 3^{\circ} \mathrm{O}$ condenado poderá demonstrar a inexistência da incompatibilidade ou a procedência lícita do patrimônio.

Encaminhado à Câmara dos Deputados (sob a rubrica do Projeto de Lei n. 882/2019), o pacote foi apensado ao Projeto de Lei n. 10.372/2018 e analisado por Grupo de Trabalho instituído com o objetivo de aperfeiçoar a legislação penal e processual penal.

O iter legislativo da perda alargada possui um capítulo paralelo com a Lei n. 13.886/2019. Esse diploma, oriundo da Medida Provisória n. 885/2019, introduziu, em seis leis, dispositivos voltados a acelerar a destinação de bens apreendidos que tenham vinculação com o tráfico de drogas. Uma das novas previsões legislativas, o recém introduzido artigo 63-F da Lei de Drogas instituiu a possibilidade de decretação da perda alargada para crimes previstos naquela lei. Oriundo de emenda aditiva apresentada por ocasião dos debates parlamentares atinentes à conversão da MP em lei, esse dispositivo consiste em cópia praticamente integral da Medida VIII do Pacote Anticrime, excetuados ajustes redacionais e o âmbito de incidência do instituto, restrito aos crimes tipificados na própria Lei n. 11.343/06 aos quais é cominada pena máxima superior a seis anos de reclusão. O que de mais relevante se deve destacar, aqui, é a manutenção do $\S 1^{\circ}$, em redação idêntica àquela acima transcrita. 
Feito esse adendo, retoma-se a narrativa quanto ao caminho percorrido pela perda alargada entre a sua proposição, no Pacote Anticrime, e a sua consagração legal. Com o apensamento dos Projetos de Lei n. 882/2019 e 10.372/2018, a disciplina da perda alargada definida pelo Grupo de Trabalho constituído na Câmara dos Deputados representou um amálgama dessas duas propostas.

A regulamentação, reproduzida no projeto encaminhado ao Plenário da Câmara dos Deputados e ao Senado Federal, foi fixada nos seguintes termos:

Art. 91-A. Na hipótese de condenação por infrações às quais a lei comine pena máxima superior a 6 (seis) anos de reclusão, poderá ser decretada a perda, como produto ou proveito do crime, dos bens correspondentes à diferença entre o valor do patrimônio do condenado e aquele que seja compatível com o seu rendimento lícito.

$\S 1^{\circ}$ Para efeito da perda prevista no caput deste artigo, entende-se por patrimônio do condenado todos os bens:

I - de sua titularidade, ou em relação aos quais ele tenha o domínio e o benefício direto ou indireto, na data da infração penal ou recebidos posteriormente; $\mathrm{e}$

II - transferidos a terceiros a título gratuito ou mediante contraprestação irrisória, a partir do início da atividade criminal.

$\S 2^{\circ} \mathrm{O}$ condenado poderá demonstrar a inexistência da incompatibilidade ou a procedência lícita do patrimônio.

$\S 3^{\circ}$ A perda prevista neste artigo deverá ser requerida expressamente pelo Ministério Público, por ocasião do oferecimento da denúncia, com indicação da diferença apurada.

$\S 4^{\mathrm{o}} \mathrm{Na}$ sentença condenatória, o juiz deve declarar o valor da diferença apurada e especificar os bens cuja perda for decretada.

$\S 5^{\circ}$ Os instrumentos utilizados para a prática de crimes por organizações criminosas e milícias deverão ser declarados perdidos em favor da União ou do Estado, dependendo da Justiça onde tramita a ação penal, ainda que não ponham em perigo a segurança das pessoas, a moral ou a ordem pública, nem ofereçam sério risco de ser utilizados para o cometimento de novos crimes. 
Como se extrai do cotejo com a versão apresentada no Pacote Anticrime, as modificações operadas pelo Congresso Nacional dizem respeito à exclusão do anterior $\S 1^{\circ} \mathrm{e}$ à inclusão dos atuais $\S \S 3^{\circ}, 4^{\circ}$ e $5^{\circ}$. Vale notar, desde já, que a exclusão do $\S 1^{\circ}$, relativo a elementos probatórios condicionantes da decretação da perda alargada, representa modificação determinante para a aferição da dinâmica probatória subjacente aos dois regimes que agora presidem a perda alargada, constantes no Código Penal e na Lei de Drogas.

Com a sanção presidencial, esse dispositivo passou a integrar o Código Penal, na forma do recém introduzido artigo 91-A.

Traçado esse caminho introdutório até a dupla chegada da perda alargada na legislação penal brasileira, passa-se ao cerne do presente estudo, atinente à dinâmica probatória subjacente à perda alargada no Código Penal e na Lei de Drogas.

\section{ENTRE A REDUÇÃo do STANDARd PROBATÓRIO E A INVERSÃo dO ÔNUS DA PROVA}

Entre as questões processuais com o potencial de gerar discussões e dissensos doutrinários e jurisprudenciais, aquela relativa à inversão do ônus da prova certamente merece destaque, como demonstra a discussão travada pela doutrina brasileira - que, em boa parte, principalmente em relação aos críticos (BOTTINI, 2020; OLIVEIRA, 2015, p. 54; SANTOS; SANTOS, 2015, p. 24) ${ }^{14}$, enfatiza a inversão do ônus da prova como algo estranho ao processo penal brasileiro.

Essa estranheza, vale apontar, não é uma exclusividade brasileira. Também em Portugal a doutrina apontou, logo após a promulgação da Lei n. 5/2002, que a inversão do ônus da prova é técnica que até então não encontrava lugar no direito processual penal luso (GODINHO, 2004, p. 1.316) ${ }^{15}$.

14 A propósito, vale destacar que o artigo 91-A do Código Penal foi impugnado, perante o Supremo Tribunal Federal, na Ação Direta de Inconstitucionalidade n. 6304, ajuizada pela Associação Brasileira dos Advogados Criminalistas (Abracrim), ainda durante de o período de vacatio legis da Lei n. 13.964/2019.

15 Talvez no Brasil não se possa dizer que a inversão do ônus da prova em matéria patrimonial seja uma técnica totalmente inédita, porque, pelo menos 
Em Portugal, a propósito, é relativamente consolidada a concepção de que a perda alargada, tal como prevista na Lei n. 5/2002, opera a partir da inversão do ônus da prova. A lei, portanto, imputa à defesa o ônus de comprovar a licitude da parcela do patrimônio do condenado em relação à qual o Ministério Público postula a decretação da perda alargada.

Essa compreensão acompanha a perda alargada desde antes mesmo da sua consagração legal. Godinho (2004, p. 1.317), por exemplo, recorda que o então Ministro da Justiça português, por ocasião do debate parlamentar acerca da Proposta de Lei n. 94/VIII, "questionado sobre se se trata de uma inversão do ónus da prova [...], reconheceu ser esse o caso". Por isso, o autor conclui, com referência à Lei n. 5/2002: “dos trabalhos preparatórios e do texto da referida Lei resulta com clareza que se trata de uma inversão do ónus da prova; o n. 1 do art. $7^{\circ}$ estabelece a regra de base".

De fato, a questão quanto à inversão do ônus da prova parece estar fora de discussão na doutrina portuguesa ${ }^{16}$, embora, ressalve-se, o mesmo não possa dizer quanto à compatibilidade constitucional dessa providência.

No Brasil, por outro lado, a inversão do ônus da prova não é assim tão óbvia, o que se deve, inicialmente, ao tortuoso caminho legislativo percorrido pela perda alargada até a sua chegada ao Código Penal e à Lei de Drogas e, ademais, a esse duplo regime confiscatório, em que se verifica que a disciplina constante em uma lei conflita com aquela presente na outra.

segundo a sua exposição de motivos, a Lei n. 9.613/98 promove uma inversão do encargo probatório em seu artigo $4^{\circ}, \S 2^{\circ}$, quando condiciona a restituição de bens sequestrados ou apreendidos à comprovação, por parte do sujeito passivo, de sua licitude. Ressalve-se que parte da doutrina aponta que essa inversão do ônus da prova opera apenas na fase cautelar (BALTAZAR, 2008, p. 521-522), ao passo que outros autores sustentam que falar em inversão do ônus da prova constitui uma imprecisão técnica, porque somente haveria, em verdade, uma redução do standard probatório (BONFIM; BONFIM, 2005, p. 95; PEZZOTTI, 2019, p. 83-89).

16 Além disso, ressalte-se que o Tribunal Constitucional português se pronunciou-se, por três vezes (Acórdãos n. 101, 392 e 476), no ano de 2015, favoravelmente à constitucionalidade da perda alargada, oportunidades em que também assentou que essa medida é efetivamente operacionalizada a partir da inversão do ônus da prova. 


\subsection{A dinÂmica probatória da perda alargada na LeI de Drogas}

No artigo 63-F da Lei de Drogas, como se afiançou, foi mantido o $\S 1^{\circ}$, originalmente previsto no Pacote Anticrime, segundo o qual "a decretação da perda prevista no caput fica condicionada à existência de elementos probatórios que indiquem conduta criminosa habitual, reiterada ou profissional do condenado ou sua vinculação a organização criminosa”.

No caput mencionam-se dois requisitos: "condenação por infrações às quais esta Lei comine pena máxima superior a 6 (seis) anos de reclusão" e "diferença entre o valor do patrimônio do condenado e aquele compatível com o seu rendimento lícito”.

Os requisitos aí mencionados são, portanto, a condenação criminal e a incongruência patrimonial. Assim, para que se requeira a perda alargada, pressupõe-se a existência de provas quanto à prática de um delito suficientes a embasar a condenação e a indicação de uma incongruência patrimonial.

Mais do que isso, todavia, o artigo 63-F da Lei de Drogas demanda que a acusação apresente "elementos probatórios que indiquem conduta criminosa habitual, reiterada ou profissional do condenado ou sua vinculação a organização criminosa". Vale atentar, aqui, à conjunção "ou”, a indicar alternatividade entre os requisitos ali citados.

Ou seja, o regime da perda alargada disciplinado na Lei de Drogas demanda a demonstração de dois requisitos compulsórios relativos à condenação criminal e à incongruência patrimonial - e de um requisito alternativo, que pode dizer respeito a "conduta criminosa habitual, reiterada ou profissional do condenado" ou à "sua vinculação a organização criminosa”.

Os requisitos compulsórios e os requisitos alternativos ${ }^{17}$ dizem respeito, portanto, a fatos diversos.

Com efeito, a condenação criminal - primeiro requisito compulsório - exige provas de autoria e de materialidade a respeito de um

17 Ainda que "alternativos" - no sentido de que a acusação pode comprovar um ou outro -, os dois requisitos mencionados pelo art. 63, § $1^{\circ}$, da Lei de Drogas também são "compulsórios", porque é necessário que pelo menos um dos dois esteja presente para que se decrete a perda alargada. 
delito específico, e não é a isso que os requisitos alternativos se referem (embora, como se verá, também se direcionem, em última análise, à comprovação de uma prévia conduta criminosa).

A prova da incongruência patrimonial - o outro requisito compulsório - também não se confunde com aquela indicada pelo requisito alternativo. Trata-se de uma prova essencialmente patrimonial, relativa à compatibilidade do patrimônio que se encontra sob domínio do condenado - de acordo com a ampla conceituação de patrimônio encontrada no artigo 63-F, \& $2^{\circ}$ - com seus rendimentos lícitos.

Os requisitos compulsórios não dizem respeito, pois, à conduta criminosa do agente ou à sua vinculação a organização criminosa. Esse requisito alternativo demanda, portanto, elementos probatórios próprios, adicionais àqueles que demonstram a satisfação dos requisitos compulsórios.

E, embora o $\S 1^{\circ}$ do artigo 63-F não o consigne expressamente, é evidente que cabe ao Ministério Público, por ocasião do requerimento de perda alargada, a produção dessa prova. Questão diversa - a ser mais adiante enfrentada - dirá respeito ao standard probatório a ser satisfeito nesse requerimento.

O $\S 3^{\circ}$ do artigo 63-F, segundo o qual "o condenado poderá demonstrar a inexistência da incompatibilidade ou a procedência lícita do patrimônio", não tem o condão de inverter esse ônus do probatório. Tal dispositivo, também presente no Código Penal (na forma do $\S 2^{\circ}$ do artigo 91-A), deve ser lido à luz dos parágrafos que o antecedem e, especialmente, à luz do que dispõe o $\S 1^{\circ}$. Se este último dispositivo prevê a necessidade da comprovação de uma conduta criminal prévia, o $\S 3^{\circ}$ não seria capaz de desnaturar tal previsão. O $\S 3^{\circ}$ deve ser lido, portanto, como uma garantia expressa do contraditório e da ampla defesa, a serem exercidos contra o pedido ministerial de decretação da perda alargada. Trata-se de disposição semelhante ao artigo $9^{\circ}$ da Lei n. 5/2002, segundo o qual "sem prejuízo da consideração pelo tribunal, nos termos gerais, de toda a prova produzida no processo, pode o arguido provar a origem lícita dos bens referidos no n. ${ }^{\circ} 2$ do artigo $7 .^{\circ}{ }^{18}$.

18 Ressalve-se que a lei portuguesa acrescenta (artigo $9^{\circ}$, item 3 ) que o condenado pode ilidir a presunção de ilegitimidade erigida pelo Ministério 
A interpretação do artigo 63-F da Lei de Drogas demonstra, portanto, que o regime aí disciplinado não se baseia na inversão do ônus da prova. Com efeito, segundo tal dispositivo legal, cabe ao Ministério Público a produção de provas adicionais, para além daquelas relativas à condenação do agente e à incongruência patrimonial, que permitam a decretação da perda alargada ${ }^{19}$.

Público se provar que os bens "a) Resultam de rendimentos de atividade lícita; b) Estavam na titularidade do arguido há pelo menos cinco anos no momento da constituição como arguido; c) Foram adquiridos pelo arguido com rendimentos obtidos no período referido na alínea anterior". Ou seja, além de simplesmente prever a evidente possibilidade de exercício do contraditório e da ampla defesa, a norma lusa impõe à perda alargada limite temporal de cinco anos (previamente à constituição do condenado como arguido).

19 A exigência desse requisito se assemelha a uma condição cunhada pela doutrina portuguesa: trata-se de uma anterior atividade (ou carreira) criminosa. Caeiro (2013, p. 494), por exemplo, sustenta que a perda alargada é vinculada a três requisitos: a condenação por um dos "crimes do catálogo"; a incongruência do patrimônio do condenado; e "a existência de uma atividade criminosa anterior do condenado, onde se incluam ilícitos do catálogo idênticos ao crime do processo em causa, ou que com ele tenham uma certa conexão". Cunha (2009, p. 135), de forma ainda mais exigente, defende que a melhor interpretação da Lei n. 5/2002 demanda prova quanto a uma anterior "carreira criminosa". Outra parte da doutrina, no entanto, é contrária à exigência desse requisito; Correia (2012, p. 110), por exemplo, afirma que "esta exigência suplementar, imposta apenas por via exegética, não tem grande justificação, acabando por redundar numa espécie de revogação interpretativa do novo regime legal". No confronto entre essas duas posições, é a segunda que tem recebido respaldo jurisprudencial. Cita-se, por exemplo, o Acórdão do Tribunal da Relação do Porto, Processo 1653/12.2JAPRT.P1, Relatora Maria Deolinda Dionísio, julgamento em 17/09/2014, em que se decidiu que "São pressupostos da aplicação da perda alargada: a condenação por um dos crimes do catálogo ( $\operatorname{art}^{\circ} 1^{\circ}$ al.a) da Lei 5/2002); a existência de um património que esteja na titularidade ou mero domínio e beneficio do condenado, património esse em desacordo com aquele que seria possível obter face aos seus rendimentos lícitos; a demonstração de que o património do condenado é desproporcional em relação aos seus rendimentos lícitos". Não se referiu, portanto, a qualquer atividade criminosa anterior. Além disso, como se indicou acima (nota 14) o Tribunal Constitucional português, nas três vezes em que confirmou a constitucionalidade da perda alargada, nada disse a respeito desse requisito adicional formulado pela doutrina e, assim, limitou-se àqueles expressamente previstos pela Lei n. 5/2002. 


\subsection{A dinâmica probatória da perda alargada no Código Penal}

No regime instituído no Código Penal, por outro lado, não se exige do Ministério Público a apresentação de provas quanto àqueles requisitos alternativos demandados pelo regime especial da Lei de Drogas.

Assim, a perda alargada baseia-se, no Código Penal, tão-somente na incongruência patrimonial e na condenação por crime cuja pena máxima seja superior a seis anos de reclusão - apenas os requisitos compulsórios, referidos por ocasião da exposição acerca do artigo 63-F da Lei de Drogas.

Em relação a esses requisitos, todavia, parece que não ocorre, de fato, a imputação de um ônus probatório ao Ministério Público; com efeito, as previsões contidas no caput dos artigos inseridos no Código Penal (art. 91-A) e na Lei de Drogas (art. 63-F), isoladamente, não impõem encargos probatórios à acusação. Quanto à condenação criminal, a prova que a subsidia não diz respeito aos bens a serem confiscados por meio da perda alargada; na verdade, essa condição figura muito mais como uma “condição de procedibilidade” à qual a perda alargada é sujeita.

No que toca à incongruência patrimonial também não parece haver a imposição de um encargo probatório à acusação. Basta que se identifique a existência de um patrimônio em nome do condenado - e isso, mais uma vez, à luz do conceito bastante amplo que se encontra no $\S 1^{\circ}$ do artigo 91-A - e que se indique que tal patrimônio é incompatível com os rendimentos lícitos do agente (que podem ser consultados, por exemplo, em sua declaração de Imposto de Renda de Pessoa Física). Essa incumbência imputada ao Ministério Público assemelha-se muito mais a uma operação comparativa (entre o patrimônio e os rendimentos lícitos) do que à efetiva produção de provas. E ainda que se interprete que a indicação da incongruência representa um ônus probatório do qual o Ministério Público deve se desincumbir, trata-se de um ônus significativamente mitigado e simplificado, para cuja satisfação é suficiente, como se disse, mera consulta a declarações de rendimentos.

No regime do Código Penal, a produção de provas fica a encargo do sujeito passivo, que deve comprovar a licitude de seu próprio patrimônio, sob pena de vê-lo confiscado.

As opiniões jurídicas a respeito da inclusão da perda alargada no Código Penal por meio da Lei n. 13.964/2019, embora ainda pouco 
numerosas, também parecem se inclinar nesse sentido, como se extrai dos argumentos de Bottini (2020) e de D’Angelo (2020).

Assim, verifica-se que a perda alargada disciplinada no Código Penal é operacionalizada a partir da inversão do ônus da prova em desfavor da defesa. Em suma, sob o aspecto probatório, o que distingue os regimes da perda alargada no Código Penal e na Lei de Drogas é, fundamentalmente, a existência, nesta última, do $\S 1^{\circ}$ - excluído da regulamentação daquele diploma -, que demanda a comprovação de requisitos além daqueles disciplinados no caput dos artigos 91-A do Código Penal e 63-F da Lei n. 11.343/06.

\subsection{ENTRE OS DIFERENTES ÔNUS DE PROVA E OS STANDARDS PROBATÓRIOS}

Após a análise da disciplina contida no Código Penal e na Lei de Drogas, a dinâmica probatória subjacente aos regimes geral e especial da perda alargada pode ser melhor diferenciada a partir de um olhar processual penal que, em primeiro lugar, distinga a inversão do ônus da prova e a redução do standard probatório.

Quanto ao encargo probatório, vale a remissão às lições de Ferrer Beltrán (2018, p. 175), que, em relação ao ônus da prova, elucida a distinção entre o burden of proof e o burden of producing evidence ${ }^{20}$ :

No primeiro sentido, a distribuição do ônus da prova supõe determinar qual das partes se verá prejudicada pela falta de prova, i.e., quem perde o processo se não se cumpre o standard de prova aplicável ao mesmo. No segundo sentido, o ônus da prova rege qual das partes deve produzir todas ou alguma prova no processo.

20 Especificamente quanto ao juízo condenatório, a distinção entre as duas espécies de ônus probatórios tem particular relevância no que toca ao encargo quanto à comprovação de excludentes de ilicitude ou de culpabilidade: Nogueira (2018, p. 271), por exemplo, afiança que "o ônus da prova das excludentes de ilicitude e culpabilidade devem ser suportados pelo acusador, não podendo haver espaço para exceções a essa regra”, ao passo que Ferrer Beltrán (2018, p. 177), pugnando por uma concepção minimalista e garantista da presunção de inocência, argumenta que "nada exclui na maioria dos sistemas jurídicos modernos, que a defesa deva integrar provas ao processo se assim se ordena, por exemplo, devido a que a ela resulta mais fácil integrá-la ou porque é ela quem dispõe da prova que se considera relevante" - ou seja, que é possível imputar à defesa o burden of producing evidence (o que não implica a imputação do burden of proof). 
A conceituação das espécies de encargos probatórios torna ainda mais clara a diferença entre os regimes probatórios subjacentes ao Código Penal e à Lei de Drogas.

No regime geral, tanto o burden of proof quanto o burden of producing evidence recaem sobre o sujeito passivo da persecução penal. Assim, diz-se que o condenado carrega o burden of producing evidence porque é a ele que incumbe comprovar a licitude de seu patrimônio. Além disso, também se imputa àquele sujeito passivo o burden of proof porque, caso não satisfaça o standard probatório, "perde" o processo - o que se traduz na declaração da perda alargada e, portanto, no confisco da parcela de seu patrimônio que se julgar incompatível com seus rendimentos lícitos.

Por outro lado, no regime especial disciplinado na Lei de Drogas, o condenado também carrega o burden of producing evidence, porque, segundo o $\S 3^{\circ}$ do artigo 63-F, ele deve - ou pelo menos pode - "demonstrar a inexistência da incompatibilidade ou a procedência lícita do patrimônio". No entanto, também à acusação é imputado o burden of producing evidence, porque é necessária a produção de provas "que indiquem conduta criminosa habitual, reiterada ou profissional do condenado ou sua vinculação a organização criminosa".

Assim, em uma primeira análise, é ao Ministério Público que compete o burden of proof, porque será ele que, na hipótese de não se satisfazer o standard probatório subjacente ao juízo confiscatório - relacionado ao caput e ao $\S 1^{\circ}$ do art. 63-F da Lei de Drogas -, "perderá” o processo, porque não logrará êxito em obter a decretação perda alargada, em desfavor do condenado.

Logo, enquanto no regime geral há uma cumulação do burden of proof e do burden of producing evidence sobre a defesa, na Lei de Drogas esses ônus são imputados ao Ministério Público, muito embora também se imponha ao condenado o ônus de produzir prova quanto à licitude de seu patrimônio. De todo modo, neste regime especial, ainda que o sujeito passivo não logre comprovar a procedência lícita de seus bens, isso não implicará em uma derrota processual, caso o Ministério Público também não se desincumba de seu ônus - aquele indicado no § $1^{\circ}$ do artigo 63-F.

A discussão em relação a essa distribuição dos diferentes ônus invoca, ainda, a reflexão quanto aos standards probatórios, definidos como “critérios que estabelecem o grau de confirmação probatória necessário 
para que o julgador considere um enunciado fático como provado" (BADARÓ, 2018, p. 71). Também conhecidos como modelos de constatação, os standards probatórios representam uma dentre as categorias e processos que visam "controlar, no quanto for possível, os subjetivismos que incidem na questão de fato"; são, assim, imbuídos da concepção de que a "metodologia do livre convencimento judicial quanto à questão fática não pode ser compreendida como local em que não exista qualquer tipo de controle jurídico" (KIRCHER, 2018, p. 204).

O standard probatório usualmente associado ao processo penal é o da prova além da dúvida razoável, vinculado, em geral, ao juízo condenatório. É esse o juízo que, em geral, suscita análises quanto à produção probatória no processo penal, em suas acepções cognitiva e persuasiva, até porque conduz à decisão "que, com a condenação, libera o exercício do poder punitivo estatal” (VASCONCELLOS, 2018, p. 715). Nada impede, todavia, que outros juízos formulados ao longo da persecução penal adotem standards probatórios diversos, a depender da fase processual e do interesse jurídico que esteja em jogo. Badaró (2011, p. 352) indica isso com bastante clareza ao afirmar que

nada impede que a técnica dos ‘modelos de constatação' seja utilizada no processo penal com vista a decisões distintas a serem proferidas ao longo da persecução penal, em especial para distinguir as decisões cautelares com base em juízo de probabilidade, das sentenças de mérito, baseada em provas "além de qualquer dúvida razoável".

Como aponta Lucchesi (2019, p. 186), "o modelo de proof beyond a reasonable doubt [...] serve tão somente à formação da decisão de mérito, ao final do processo"; sob o fundamento de que "é necessário estabelecer critérios para cada fase processual” (2019, p. 166), o autor propõe, então, que "a relação entre a carga probatória, a presunção de inocência e a decisão judicial seja compreendida e delimitada para cada fase processual, a fim de que se possa determinar qual deve ser o critério para a decisão judicial durante o processo" (2019, p. 186).

Por isso, mesmo no processo penal, os juízos vinculados a temas exclusivamente patrimoniais usualmente são formulados sob o crivo do standard probatório da preponderância de evidências, tipicamente utilizado no processo civil. 
Caeiro (2013, p. 498), nesse sentido, alude aos ordenamentos jurídicos britânico (que se vale da fórmula "on the balance of the probabilities”), espanhol, holandês, francês, italiano e português como exemplos nos quais as questões relativas ao confisco são decididas a partir desse modelo de constatação intermediário, tipicamente civil.

A menção aos standards probatórios é relevante porque a utilização de um modelo de constatação inferior ao da prova além de qualquer dúvida razoável é um dos aspectos em que a perda alargada se distancia da perda clássica. Com efeito, como os bens que constituem o objeto da perda clássica (na forma do artigo 91 do Código Penal, o "produto do crime" e "qualquer bem ou valor que constitua proveito auferido pelo agente com a prática do fato criminoso") devem estar diretamente vinculados a um crime, a sua decretação demanda que o Ministério Público satisfaça o standard probatório mais exigente: o da prova além de qualquer dúvida razoável. Aqui, portanto, o juízo condenatório e o juízo confiscatório estão indissociavelmente vinculados.

Na perda alargada, por outro lado, a condenação criminal é apenas uma condição para a sua decretação, de forma que os bens a serem confiscados não estão diretamente vinculados a qualquer delito - até porque, se estivessem e se esse nexo fosse demonstrado, seria o caso de decretação da perda clássica. Assim, em razão dessa dissociação entre o juízo condenatório e o juízo confiscatório, é possível a utilização de um standard probatório inferior: o da preponderância de evidências.

Dessa forma, a despeito da existência de diferenças entre os regimes disciplinados no Código Penal e na Lei de Drogas, ambos são guiados por esse modelo de constatação menos exigente. No Código Penal, no entanto, além de haver essa mitigação do standard probatório, há a inversão do correspondente ônus.

Assim, tanto em um caso como no outro, o sujeito processual ao qual incumbe o burden of proof deve demonstrar a preponderância de evidências em favor de sua hipótese: no Código Penal, o condenado deve indicar que preponderam evidências quanto à procedência lícita de seu patrimônio; na Lei de Drogas, o Ministério Público, além de indicar a incongruência patrimonial, deve comprovar, também à luz de uma preponderância de evidências, a "conduta criminosa habitual, reiterada ou profissional do condenado ou sua vinculação a organização criminosa”. 
Em síntese, essa distinção quanto aos sujeitos processuais aos quais incumbe a satisfação do standard probatório e do correspondente burden of proof reforça: no Código Penal, há efetiva inversão do ônus da prova em desfavor da defesa, ao passo que o mesmo não ocorre na Lei de Drogas.

\section{REPERCUSSÕES DA INVERSÃo do ÔNUS DA PROVA NA DISCIPLINA COMUM DA PERDA ALARGADA}

Verificada a dinâmica probatória subjacente aos regimes de perda alargada consagrados na legislação brasileira, cabe discorrer a respeito das repercussões daí decorrentes.

A identificação de que a perda alargada, tal como regulamentada no Código Penal, opera a partir da inversão do ônus da prova traz consigo alguns problemas e desafios.

Em primeiro lugar, cabe citar o fato de que, diante da duplicidade de regimes regulatórios da perda alargada - um no Código Penal, outro na Lei de Drogas -, há dissonâncias entre as regras a serem aplicadas a cada caso. Especificamente em relação à distribuição do ônus probatório, o regime constante na lei especial é muito mais benéfico para os réus do que aquele disciplinado na lei geral, porque imputa à acusação o ônus de produzir provas adicionais que permitam satisfazer um dos requisitos do artigo 63-F, § $1^{\circ}$. Trata-se uma situação um tanto paradoxal, uma vez que o regime geral previsto no Código Penal, em razão da ampla delimitação do âmbito de incidência delineada no caput do artigo 91-A - a atingir todos os crimes com pena máxima superior a seis anos de reclusão -, pode abranger delitos cuja gravidade em abstrato é, em geral, inferior àquela ínsita aos crimes tipificados na Lei de Drogas.

Conjecture-se, por exemplo, o caso do crime de furto na forma qualificada - ao qual é cominada pena de dois a oito anos de reclusão, e multa -, que ilustra que, mesmo em situações triviais e de gravidade mitigada, como a de um furto cometido "mediante concurso de pessoas" (artigo 155, IV, do Código Penal), o Código Penal sujeitaria os condenados a um regime confiscatório muito mais severo do que aquele aplicável a sujeito acusado da prática do crime de tráfico de 
drogas $^{21}$, mesmo sendo este, por previsão constitucional (artigo $5^{\circ}$, XLIII), um crime equiparado a hediondo.

A situação chama a atenção, a propósito, à desproporção que permeia a disciplina da perda alargada no Código Penal. Até aqui, enfatizou-se a questão vinculada à inversão do ônus da prova, que, por si só, suscita múltiplos problemas. Há, todavia, dois outros componentes que tornam ainda mais complexa a equação: a má delimitação do âmbito de incidência da perda alargada e a ausência de limitação temporal.

Quanto à delimitação do âmbito de incidência, trata-se de escolha legislativa peculiar, que fugiu completamente à tendência que vinha se desenhando em todos os projetos de lei em que se propôs a adoção da perda alargada. Com efeito, considerando os quatorze projetos que tramitam ou tramitaram no Congresso Nacional (mencionados na nota 11, supra), verifica-se que há, em geral, duas "fontes": os pacotes das Dez Medidas Contra a Corrupção e das Novas Medidas Contra a Corrupção. Dos quatorze projetos, treze deles se valem, implícita ou explicitamente, das propostas contidas naqueles pacotes legislativos. Há, além disso, o Projeto de Lei n. 10.372/2018, que, como se pontuou, foi redigido pelo Ministro Alexandre de Moraes.

Em todas essas propostas legislativas, havia uma delimitação muito mais específica do âmbito de incidência da perda alargada. Nos aludidos pacotes legislativos anticorrupção há um rol de crimes aos quais aquela espécie de confisco é aplicável - delitos que, em geral, se adéquam à acepção da delinquência econômica. No PL n. 10.372/2018, por outro lado, a perda alargada é reservada tão somente aos delitos de organização criminosa ${ }^{22}$.

21 Se, em outra hipótese, a acusação pelo crime de tráfico de drogas for acompanhada de imputação relativa ao crime de organização criminosa, parece possível a aplicação do regime confiscatório "geral”, previsto no Código Penal, porque os crimes tipificados na Lei n 12.850/13 - como quaisquer outros, à exceção daqueles previstos na Lei de Drogas - estão sujeitos ao regramento contido no artigo 91-A do Código Penal. Por outro lado, pode-se argumentar que, diante do conflito aparente de normas, prevaleceria a lei especial - no caso, a Lei de Drogas. Sem pretensões futurológicas, parece seguro afiançar que a questão desafiará divergências doutrinárias e jurisprudenciais.

Essa proposta de delimitação converge, por exemplo, com as ideias defendidas por Linhares (2016, p. 194), para quem o ideal seria a conjugação do rol taxativo presente em propostas como as das Dez e das Novas Medidas Contra a Corrupção, com a exigência de que os crimes tenham sido praticados "no marco de uma organização criminosa". 
Em Portugal, da mesma forma, a decretação da perda alargada é vinculada à condenação do sujeito passivo por um dos "crimes do catálogo" - isto é, os crimes arrolados no artigo $1^{\circ}$ daquele diploma.

O Pacote Anticrime - e, consequentemente, a Lei n. 13.964/19adotou técnica legislativa pouco usual quanto a esse aspecto, e delimitou o âmbito de incidência da perda alargada com base tão-somente no limite máximo da pena (de seis anos de reclusão, em momento algum justificado) abstratamente cominada à infração penal.

Somado ao bastante amplo (e mal delimitado) âmbito de incidência da perda alargada, tem-se, ainda, aspecto ainda mais grave: a completa ausência de limite temporal para a decretação da perda alargada.

Tanto nos pacotes das Dez Medidas e das Novas Medidas, quanto no Projeto de Lei n. 10.372/2018, impôs-se um limite de cinco anos à perda alargada (interregno que remete, por exemplo, aos prazos prescricionais e decadenciais na esfera tributária), contados retroativamente a partir de marcos temporais diversos (a data de oferecimento ou recebimento da denúncia, no caso desta última proposta; a data de instauração da investigação, no caso daqueles pacotes legislativos). A proposta do Projeto Alexandre de Moraes inclusive menciona que, para ilidir a presunção de ilicitude dos bens que constituem a incongruência patrimonial, pode a defesa comprovar que os bens estavam na titularidade do condenado há pelo menos cinco anos, contados do oferecimento da denúncia, em dispositivo semelhante ao artigo $7^{\circ}$, item 2, b e $c$, da Lei n. 5/2002, de Portugal.

No diploma português, a propósito, a limitação temporal alcança os cinco anos anteriores à constituição do sujeito como arguido, como define o artigo $7^{023}$.

O artigo 91-A do Código Penal, por sua vez, nada dispõe acerca de eventuais limites temporais, em aspecto observado também no artigo 63-F da Lei de Drogas.

Assim, conjugados esses aspectos relativos a delimitações inadequadas - no caso do âmbito de incidência - ou inexistentes - no caso do limite temporal -, verifica-se que, seja no Código Penal, seja na Lei

23 Ainda no âmbito internacional, vale a referência à legislação do Reino Unido - o Proceeds of Crime Act, de 2002 -, em que há um limite temporal de seis anos, semelhante àquela presente na lei portuguesa. 
de Drogas, a perda alargada tem uma dimensão bastante considerável porque permite, na prática, que se alcance o patrimônio amealhado pelo condenado ao longo de toda a sua vida, desde a sua mais tenra idade.

O regime do Código Penal é, nesse aspecto, ainda mais severo, porque, ao suprimir os requisitos alternativos hoje presentes no $\S 1^{\circ}$ do artigo 63-F da Lei de Drogas, imputa ao sujeito passivo tanto o burden of proof quanto o burden of producing evidence, isto é, o ônus de comprovar a licitude de absolutamente todo o seu patrimônio, sem qualquer limitação temporal ${ }^{24}$. Em um país cuja economia informal alcança dimensões bastante consideráveis ${ }^{25}$, trata-se de um encargo bastante substancial.

A propósito, embora não seja este o mote do presente trabalho que buscou, primordialmente, identificar a dinâmica probatória subjacente aos regimes geral e especial da perda alargada - não se pode deixar de anotar, nestas últimas linhas, que a perda alargada, além de representar uma inovação legislativa significativa, flerta perigosamente com a violação aos preceitos elementares do Direito Penal e Processual Penal brasileiro.

Sobretudo por conta da rigidez que caracteriza o regime geral instituído no Código Penal - aplicável a toda a legislação penal brasileira, à exceção da Lei de Drogas (que, paradoxalmente, prevê um regime atenuado) -, a perda alargada representa ameaça ou até efetiva violação a preceitos tais como a presunção de inocência, o direito à não autoincriminação, a proporcionalidade e até mesmo o direito fundamental à propriedade privada.

Trata-se, de todo modo, de questão a ser enfrentada em pesquisas apartadas, que se aprofundem em relação à compatibilidade da perda alargada com os preceitos constitucionais acima (não exaustivamente) mencionados.

24 É claro que se pode conjecturar que a jurisprudência, em homenagem ao princípio da proporcionalidade e à proteção da propriedade privada, imponha um limite temporal à perda alargada, com o recurso à analogia e consequente aplicação de outros dispositivos legais que imponham limites temporais ao poder estatal. Em análise de lege ferenda, Essado (2014, p. 175) sugeriu a adoção do prazo de cinco anos para a cobrança judicial do crédito tributário (Lei 5.172/1966, artigo 174).

25 O Índice de Economia Subterrânea aponta que, em 2019, 17,3\% do PIB do país foi movimentado pela economia informal. Disponível em: bit.ly/2U86hvN. Além disso, pesquisa recente mostra que, em 2017, 40,3\% da população economicamente ocupada desempenhava trabalhos informais: bit.ly/38muXH9. 


\section{Considerações Finais}

O presente artigo se debruçou sobre a perda alargada, e buscou apreciar um aspecto processual em particular, atinente à dinâmica probatória subjacente àquela espécie de confisco. Intentou-se responder, mais precisamente, à seguinte indagação: os regimes instituídos no artigo 91-A do Código Penal e no artigo 63-F da Lei de Drogas promovem inversão do ônus da prova em desfavor do réu?

Para tanto, a partir do método dedutivo e do procedimento de pesquisa bibliográfico, este trabalho teve início com uma exposição panorâmica a respeito dos antecedentes legislativos e das razões políticocriminais que dão sustento à perda alargada e que a fazem se expandir. Apresentou-se, ainda, o tortuoso percurso legislativo da perda alargada, que culminou com a sua consagração no artigo 63-F da Lei de Drogas e no artigo 91-A do Código Penal. Essa análise revelou-se fundamental para que se compreendessem as vicissitudes que permeiam tal medida patrimonial.

Na sequência, passou ao cerne da pesquisa: buscou-se, então, compreender a dinâmica probatória a partir da qual é operacionalizada a perda alargada, especificamente para que se identificasse se de fato há, nos regimes geral e especial daquela modalidade de confisco, inversão do ônus da prova. Para tanto, discorreu-se, inicialmente, a respeito do regime disciplinado na Lei de Drogas, oportunidade em que se verificou que, como o $\S 1^{\circ}$ do artigo 63-F impõe ao Ministério Público a produção de provas quanto à conduta criminosa do condenado ou à sua vinculação a organização criminosa, isso implica a inexistência da inversão do ônus da prova. Com o caminho pavimentado pela análise anterior, passou-se, então, a apreciar o regime geral. Verificou-se que, como aqueles requisitos alternativos previstos na Lei de Drogas foram suprimidos do Projeto de Lei que introduziu o artigo 91-A do Código Penal, isso desincumbiu o Ministério Público de produzir qualquer prova adicional, de modo que basta a obtenção da condenação criminal e a indicação de incongruência patrimonial; e, concomitante, imputou-se ao réu o ônus - o burden of proof e o burden of producing evidence - de comprovar a licitude de seu próprio patrimônio.

A partir dessa constatação, passou-se à reflexão a respeito das decorrências dessa dinâmica probatória, cuja rigidez é acentuada no regime geral previsto no Código Penal, precisamente por conta da inversão do ônus da prova em desfavor da defesa. Acrescentou-se, ainda, que tal 
encargo - por si só substancial - é agravado pelo fato de que ambos os regimes disciplinados pelo legislador não impõem limitações temporais à decretação da perda alargada, que terá por objeto, portanto, a integralidade do patrimônio amealhado pelo condenado ao longo de toda sua vida. Observou-se, ademais, o paradoxo resultante da instituição, na Lei de Drogas, de um regime não tão rígido quanto aquele consagrado no Código Penal, o que, mais uma vez, se deve à distinção quanto à exigência, ou não, de requisitos alternativos (para além dos compulsórios).

Ao cabo do trabalho, verifica-se que a hipótese introdutoriamente articulada foi verificada, uma vez que se constatou que a resposta ao problema de pesquisa não é, de fato, unívoca: há inversão do ônus da prova no Código Penal, e não há na Lei de Drogas.

Ao final ainda cabe registrar que o caminho aqui traçado - um incipiente estudo processual da perda alargada - permite vislumbrar outras rotas a serem traçadas em pesquisas futuras. É fundamental, por exemplo, um aprofundamento na natureza jurídica e no caráter - penal ou extrapenal - da perda alargada. Além disso, a matéria demanda um estudo sistemático relativo à compatibilidade desse novo instrumento com a ordem constitucional, até porque os tribunais certamente se depararão, em breve, com questionamentos nesse sentido.

De todo modo, no vasto leque de questões relativas à perda alargada a serem estudadas, este artigo buscou propiciar a compreensão a respeito de um aspecto fundamental, atinente à dinâmica probatória do instituto e à inversão do ônus da prova nos regimes adotados no Código Penal e na Lei de Drogas.

\section{REFERÊNCIAS}

BADARÓ, Gustavo H. Editorial dossiê "Prova penal: fundamentos epistemológicos e jurídicos". Revista Brasileira de Direito Processual Penal, Porto Alegre, vol. 4, n. 1, p. 43-80, jan./abr. 2018. https:/doi.org/10.22197/rbdpp.v4i1.138

BADARÓ, Gustavo H. Direito a um julgamento por juiz imparcial: como assegurar a imparcialidade objetiva do juiz nos sistemas em que não há a função do juiz de garantias, In: BONATO, Gilson (Org.). Processo Penal, Constituição e Crítica Estudos em Homenagem ao Prof. Dr. Jacinto Nelson de Miranda Coutinho. Rio de Janeiro: Lumen Juris, 2011, p. 343-364. Disponível em: https://goo.gl/XssrqX. Acesso em 06. maio 2020. 
BALTAZAR JR., José Paulo. Crimes federais. 3a ed. Porto Alegre: Livraria do Advogado, 2008.

BONFIM, Edilson Mougenot; BONFIM, Marcia Monassi Mougenot. Lavagem de dinheiro. São Paulo: Malheiros, 2005.

BOTTINI, Pierpaolo Cruz. Direito penal, processo penal e colaboração premiada na lei “anticrime”. Consultor Jurídico. 6. jan. 2020. Disponível em: bit.ly/2usMrSy. Acesso em 06 maio. 2020.

CAEIRO, Pedro. Sentido e função do instituto da perda de vantagens relacionadas como o crime no confronto com outros meios de prevenção da criminalidade reditícia (em especial, os procedimentos de confisco e a criminalização do enriquecimento “ilícito”). Revista Brasileira de Ciências Criminais, São Paulo, v. 21, n. 100, p. 454-501, jan.-fev. 2013.

CARDOSO, Luiz Eduardo Dias; SOUZA, Claudio Macedo de. A perda alargada em face da principiologia processual penal brasileira. Revista Brasileira de Ciências Criminais, v. 118, jan.-fev. 2016.

CORREIA, João Conde. Da proibição do confisco à perda alargada. Lisboa: INCM, 2012.

CUNHA, José Manuel Damião da. Perda de bens a favor do Estado. Arts. $7^{\circ}-12^{\circ}$ da Lei n. 5/2002. de 11 de janeiro (medidas de combate à criminalidade organizada $e$ económico-financeira). Direito Penal Econômico e Europeu: textos doutrinários. Coimbra: Coimbra Editora, 2009.

D’ANGELO, Andréa Cristina. Breves considerações sobre o confisco alargado. Jota. 25 fev. 2020. Disponível em: bit.ly/39AV6RM. Acesso em 06 maio. 2020.

DIAS, Maria do Carmo Saraiva de Menezes da Silva. "Perda alargada” prevista na Diretiva 2014/42/EU (artigo 5. ${ }^{\circ}$ ) e "perda do valor de vantagem de atividade criminosa” prevista na Lei n. ${ }^{\circ}$ 5/2002 (artigos $7 .^{\circ}$ a $12 .^{\circ}$ ). In: CARDOSO, Elina Lopes; CORREIA, João Conde; FERREIRA, Maria Raquel Desterro (coord.). $O$ novo regime de recuperação de ativos à luz da Diretiva 2014/42/UE e da Lei que a transpôs. Lisboa: INCM, 2018.

DUARTE, Ana Patrícia Cruz. O Combate aos Lucros do Crime - O mecanismo da "perda alargada" constante da Lei n.o 5/2002 de 11 de Janeiro: a inversão do ónus da prova nos termos do artigo 7. ${ }^{\circ}$ e as suas implicações. 2013. 53 f. Dissertação Curso de Direito, Universidade Católica Portuguesa, Porto, 2013. p. 14.

FERRER BELTRÁN, Jordi. Uma concepção minimalista e garantista de presunção de inocência. Revista Brasileira de Direito Processual Penal, Porto Alegre, vol. 4, n. 1, p. 149-182, jan./abr. 2018. https://doi.org/10.22197/rbdpp.v4i1.131 
GODINHO, Jorge A. F. Brandos costumes? O confisco penal com base na inversão do ónus da prova (Lei $\mathrm{n}^{\circ} 5 / 2002$, de 11 de janeiro, artigos $1^{\circ}$ e $7^{\circ}$ a $12^{\circ}$. In: ANDRADE, Manuel da Costa et al. (Org.). Liber Discipulorum para Jorge Figueiredo Dias. Coimbra: Coimbra Editora, 2003. p. 1.315-1.365.

KIRCHER, Luís Felipe Schneider. O Convencimento Judicial e os Parâmetros de Controle sobre o Juízo de Fato: visão geral, Direito Comparado e o Tribunal Penal Internacional. Duc In Altum - Cadernos de Direito, v. 10, n. 20, p. 179-206, 2018. https://doi.org/10.22293/2179-507x.v10i20.692

LINHARES, Solon. Confisco de bens: uma medida penal, com efeitos civis contra a corrupção sistêmica. São Paulo: Revista dos Tribunais, 2016.

LUCCHESI, Guilherme Brenner. Confisco alargado: análise das medidas para a recuperação de bens de origem ilícita na experiência comparada americana. In: LEITE, Alaor; TEIXEIRA, Adriano (Org.). Crime e política: corrupção, financiamento irregular de partidos políticos, caixa dois eleitoral e enriquecimento ilícito. São Paulo: FGV Editora, 2017.

MALAN, Diogo. Notas sobre a investigação e prova da criminalidade econômicofinanceira organizada. Revista Brasileira de Direito Processual Penal, Porto Alegre, vol. 2, n. 1, p. 213 - 238, 2016. http://dx.doi.org/10.22197/rbdpp.v2i1.22

NOGUEIRA, R. F. Ônus da prova das excludentes de ilicitude no processo penal e a necessidade de rompimento com a sua matriz civilista. Revista Brasileira de Direito Processual Penal, v. 4, n. 1, p. 243-275, 2018. https://doi.org/10.22197/ rbdpp.v4i1.124

OLIVEIRA, Juliana Magalhães Fernandes et al. Como Combater a Corrupção? Uma avaliação de impacto legislativo de propostas em discussão no Congresso Nacional. Brasília: Núcleo de Estudos e Pesquisas/CONLEG/Senado, jul. 2015, Texto para Discussão $n^{\circ}$ 179. Disponível em: www.senado.leg.br/estudos. Acesso em 06 maio 2020.

PEZZOTTI, Olavo Evangelista. Apontamentos sobre o confisco nos crimes de tráfico de entorpecentes e de lavagem de dinheiro. Revista Fórum de Ciências Criminais, Belo Horizonte, ano 6, n. 11, p. 61-101, jan.-jun. 2019.

RIOS, Rodrigo Sánchez; PUJOL, Luiz Gustavo. Confisco alargado: reflexões acerca de suas possibilidades no ordenamento jurídico brasileiro. Revista Brasileira de Ciências Criminais, São Paulo, v. 24, n. 118, p. 123-158., jan.-fev. 2016.

RODRIGUES, Hélio Rigor. Perda de bens no crime de tráfico de estupefacientes: harmonização dos diferentes regimes jurídicos aplicáveis. Revista do Ministério Público, v. 134, abr.-jun. 2013, p. 189-244.

SÁNCHEZ, Jesús-Maria Silva. A expansão do Direito Penal: aspectos da política criminal nas sociedades pós-industriais. Série as Ciências Criminais no século XXI. v. 11. Trad. Luiz Otavio de Oliveira Rocha. São Paulo: Revista dos Tribunais, 2002. 
SANTOS, Juarez Cirino dos; SANTOS, June Cirino dos. Reflexões sobre Confisco Alargado. Boletim IBCCRIM, ano 23, n. 277, dez. 2015, p. 23-24.

SIMÕES, Euclides Dâmaso. A proposta de Lei sobre o Gabinete de Recuperação de Activos (um passo no caminho certo). Direito Contra-Ordenacional, Revista do CEJ, $2^{\circ}$ Semestre, n. 14, Coimbra, Almedina, 2010.

SIMÕES, Euclides Dâmaso; TRINDADE, José Luís F. Recuperação de activos: Da perda ampliada à actio in rem (Virtudes e defeitos de remédios fortes para patologias graves). Revista Julgar on-line, 2009, p. 3. Disponível em julgar.pt/. Acesso em 06 maio 2020.

VASCONCELOS, André Prado de. Extinção civil de domínio - perdimento de bens: uma análise comparada: Brasil-Estados Unidos. Belo Horizonte: Del Rey, 2010.

VASCONCELLOS, Vinicius Gomes de. A prova no processo penal: a importância da valoração do lastro probatório e de seu controle por meio recursal. Revista Eletrônica do Curso de Direito da UFSM, v. 13, n. 2, p. 695-721, 2018. http://doi. org/10.5902/1981369430012

VIEIRA, Roberto D’Oliveira. Análise de direito comparado do confisco alargado: aportes da perda alargada para o Brasil. 2017. 135 f. Dissertação (Mestrado) Curso de Direito, Universidade Católica de Brasília, Brasília, 2017.

\section{Informações adicionais e declarações dos autores}

Declaração de conflito de interesses (conflict of interest declaration): o autor confirma que não há conflitos de interesse na realização das pesquisas expostas e na redação deste artigo.

Declaração de autoria e especificação das contribuições (declaration of authorship): todas e somente as pessoas que atendem os requisitos de autoria deste artigo estão listadas como autores; todos os coautores se responsabilizam integralmente por este trabalho em sua totalidade.

Declaração de ineditismo e originalidade (declaration of originality): o autor assegura que o texto aqui publicado não foi divulgado anteriormente em outro meio e que futura republicação somente se realizará com a indicação expressa da referência desta publicação original; também atesta que não há plágio de terceiros ou autoplágio. 


\section{Dados do processo editorial}

(http://www.ibraspp.com.br/revista/index.php/RBDPP/about/editorialPolicies)

- Recebido em: 31/03/2020

- Controle preliminar e verificação de plágio: 04/04/2020

- Avaliação 1: 15/04/2020

- Avaliação 2: 17/04/2020

- Avaliação 3: 27/04/2020

- Decisão editorial preliminar: 05/05/2020

- Retorno rodada de correções: $20 / 05 / 2020$

- Decisão editorial final: 29/05/2020
Equipe editorial envolvida

- Editor-chefe: 1 (VGV)

- Editor-associado: 1 (JJEC)

- Revisores: 3

\section{COMO CITAR ESTE ARTIGO:}

CARDOSO, Luiz Eduardo Dias. A inversão do ônus da prova na decretação da perda alargada: entre o Código Penal e a Lei n. 11.343/06. Revista Brasileira de Direito Processual Penal, Porto Alegre, vol. 6, n. 2, p. 799-832, maio/ago. 2020. https://doi.org/10.22197/rbdpp.v6i2.362

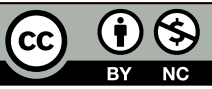

Esta obra está licenciada com uma Licença Creative Commons Atribuição-NãoComercial 4.0 Internacional. 